\title{
Innovative Judicial Methods in France to Detect the Fraud of Individuals to Obtain Administrative Decisions
}

\author{
Dr. Bassam Abu Irmilah \\ Associated Professor at Jadara University \\ Faculty of Law \\ Jordan, Irbid \\ brmkl@yahoo.com
}

\begin{abstract}
Individuals may resort to fraud or cheat the administrative authority to obtain administrative decisions, so this study seeks to outline this spread negative phenomenon, which entered all areas of the state. In this case, individuals get an administrative decision as a result of using fraudulent methods, with the intention of misleading the administration, to reach an illegal purpose that causes it to issue its decision. The importance of this study that it sheds light on the latest developments that have occurred in the French State Council's oversight of administrative decisions. The study concluded that the idea of fraud within the rules of administrative law is surrounded by provisions that are separate from the provisions of fraud in civil and criminal law, and that the administrative decision that based on fraud is a decision that is independent of the null decision, and it also constitutes a separate administrative theory in France's administrative law.
\end{abstract}

Keywords: Administrative Law, Administrative Decision, Fraud, Null Administrative Decision, Withdrawal of Administrative Decision.

\section{Introduction}

Fraud links to the human nature in all societies that have come to acknowledge its existence as a permanent global phenomenon, as the phenomenon of fraud exists in all areas of life, and in all branches of law. Therefore, the topic of "combating social fraud" has become one of the axes of social policies in all countries. In this context, Mr. Daniel Buchet, head of the Department of Risk Control and Anti-Fraud in France, notes: "Individual' fraud is practiced widely in society" (Buchet, 2006).

As a result, the French State Council (F.S.C.) organized a seminar entitled "Combating administrative and social fraud" aimed at highlighting the most prominent types of fraud and cheat in society, as well as ways and means to combat it. French Vice-Premier Mr. Sauvé pointed out that fraud and cheat are used in many areas. There is administrative fraud, commercial fraud, tax fraud, electronic fraud ... etc. (Sauvé, 2011).

Cheat in the area of administrative decisions is considered one of the most important types of fraud that individuals engage in before administrative authorities, in order to obtain an administrative decision. Fraud acts in this context mean the use of fraudulent methods by some individuals that lead the administration to issue a decision, so that these fraudulent methods involve a physical element that includes words, deeds, or forged or unreal documents. It also contains a mental element based on the intention of cheating to reach an illegal purpose. Hence, the importance of this study lies in protecting the principle of legality, against all those who seek to circumvent it in tortuous ways, in order to obtain a decision that may appear at first sight to the administration to be legal or legitimate.

The subject of the study raises some problems, the most prominent of which are: The decision taken based on cheating is productive for its legal effects in the event that the administration does not reveal the fraud case, despite it being a null decision in nature. At the judicial level, the role of the French administrative judiciary in proving the existence of fraud in the administrative decision is considered one of the most difficult tasks facing the French judge, as it must prove the availability of the element of intent in the practice of this fraud by individuals. There is also difficulty in determining the extent to which the beneficiary is aware of the decision about the fact of fraud in the event that it is committed by another person.

In light of these problems, the study raises some important questions, most notably: What is the legal nature of the decision issued based on fraud? Can this fraud constitute a criminal offense, or is it an autonomous administrative theory in its dimensions? Can the administration assume that fraud occurred? What are the modern methods used by the French administrative judiciary to uncover the fact of fraud in the administrative decision? This study attempts to answer these important questions by highlighting opinions of jurisprudence and judgments in this regard. 


\section{The Legal Concept of a Decision Based on Fraud and its Terms}

This study attempts to clarify the trends of jurisprudence and administrative jurisdiction in France towards defining the legal concept of the decision issued by the administration based on the presence of fraud by one of the individuals. Then I highlight the special conditions that must be met in this decision.

\subsection{Juristic and Judicial Concept of a Decision Issued based on Fraud in France}

The most important doctrinal and judicial trends that confronted to clarify the legal concept of the administrative decision issued based on practices in which individuals who benefit from the issuance of the decision use some types of fraud and cheat without the knowledge of administrative authority as follows:

\subsubsection{The Concept of a Decision Made based on Fraud According to French Jurisprudence}

Some jurists went to reject the decision issued based on fraud from the beneficiary to the idea of acquired rights, in contrast many of the jurisprudence went to reject that idea on the basis that decisions obtained through fraudulent methods such as fraud cannot be truly born, so it can always be reversed because it goes down to the level of physical work that produces no legal effects (Odent, 1981). While another aspect of French jurisprudence defined the decision based on fraud as: "The decision that is issued as a result of the individual using fraudulent means that deceives the administrative authority to get it to issue the decision, in this case the withdrawal of the decision by the administration is not subject to any time restriction" (Austry, 2004).

The views of administrative jurisprudence in France - despite their differing perceptions about the basis of the decision based on a case of fraud - they agreed that such a decision is born dead and cannot be said to exist, so it is considered a pure physical act that plunges its faults to the point of absence. For example, in the event that a decision is issued to appoint an employee as a result of presenting false certificates, then it cannot be said that there is an administrative decision, but rather we are in the absence of a work that does not produce a significant impact on its duration, given that the will of the administration did not tend to make any impact for it.

\subsubsection{The Concept of a Decision Taken based on Fraud According to the Jurisdiction of the French State Council}

The French State Council explicitly stated in one of its recent judgementthat the decision taken by the administration as a result of exercising of the beneficiary from the decision a kind of fraud or cheat is an illegal decision that was established by way of fraud on the administration, so it is a decision that came as a result of a material error of the administration in not checking the material facts that based on its decision, the administration may correct this error by withdrawing or canceling the decision at any time, provided that the decision to withdraw or cancel it is a sufficient and clear cause (F.S.C., 5 feb. 2018, Société Cora, $\mathrm{N}^{\circ} 407149$ ). In another verdict of the French State Council, it made it clear that the decision obtained intentionally using fraudulent and cheating means to mislead the administration does not create rights, and it can be withdrawn at any time, just as it is in the case of a null decision.(F.S.C., 19 Apr. 2000, req. $\mathrm{N}^{\circ}$ 157292).

\subsection{Conditions of a Decision Issued based on Fraud}

A part of French jurisprudence addressed the conditions that must be met in the decision based on a case of fraud cheat on the administration, as follows:

\subsubsection{Practicing Fraud or Cheat by the Beneficiary or with his Knowledge}

In order for the administrative decision to be the result of committing a case of fraud, it is required that the stakeholder or the beneficiary commit cheat or fraudulent methods, as this condition is essential to describe the decision as fraud decision (Odent, 1981), such as the beneficiary submitting forged documents, false declaration or giving false data that would mislead the administration. Fraud may also take a negative image, as the stakeholder intentionally concealing facts that might influence the decision (De Laubadere \& Gaudemet, 2001). This is what the French State Council decided upon, considering that the silence of the individual in some cases is a fraud if he intentionally conceals some basic information that he knows the administration relies on in issuing the decision and did not explicitly request it from him (Santulli, 2001). However in the case if the administration didnot request the beneficiary to provide it with certain data or information, the general rule is that the individual haven't be subjected to harmed by this administration negligence, because it is not permissible to punish the individual with a common mistake between him and the administration (Auvret, 1985).

If acts of fraud are issued by someone other than the beneficiary, then the French jurisprudence distinguishes between two cases: the case if the beneficiary knows the case of fraud, here the French jurisprudence settles that if there is sufficient evidence that the beneficiary is aware of the fact of fraud because there is a relationship between him and the person who cheated, then in this case, the beneficiary is definitely a partner in the process, so the decision here is based on fraud against the beneficiary, because he remained silent and did not give the information he knows, because the administration is ignorant of it and influences its decision, in this case the decision is based 132 
on fraud from his intended silence. Therefore, administrative authority has the right to withdraw the decision at any time without being limited of the sixty days required for the appeals (Chapus, 2001; Yannakopoulos, 1997).

This trend was also adopted by the French State Council. The French State Council decided in one of its verdicts that one of the individuals submitted a false statement of the company's annual income to circumvent the tax administration with a view to issuing a decision that reduces the value of the taxes due on the company, making the other partner an actual participant in the process of tax fraud, even if he did not do it personally, as long as he is aware - as a partner - of this fraud, however, he is silent about showing the truth as a beneficiary of the decision (F.S.C., July 13 2011, Société M., N³46743).

The second case is the case where the beneficiary is not aware of the fraud, and if someone else cheats, but the recipient does not know about the fraud, or he is not necessarily aware of it, then in this case the decision is not issued to the beneficiary as a result of the fraud, because one of the established principles is that fraud does not It is assumed that there must be strong evidence or evidence to confirm it (Forge, 2002; Giraud, 2014).

The judicial direction of the French Council of State has settled on that the beneficiary shouldn't be harmed by the decision issued on the basis of fraud if he is not aware of the knowledge of the fraud, because the basis for the null decision in this case is to punish the fraudulent himself and deny him the result of his work. In implementation of this, the French State Council indicated in one of its recent verdicts that the beneficiary's lack of knowledge that the decision issued by the mayor to grant a building permit for the rehabilitation and expansion of a residential complex was based on the use of fraudulent means from the applicant by giving incorrect data on the area of expansion It makes the fraud incident not valid against him, considering that his intention was not to mislead the municipal administration and that he was well-intentioned by the evidence that he provided the municipality with the correct information about the project area as soon as he became aware of the fraud case by the applicant (F.S.C., March 23, 2015, Loubier, $\mathrm{N}^{\circ}$ 348261).

\subsubsection{Requirement that Fraud be the Main Reason for the Decision}

It is not sufficient to consider the decision issued by the administration as a result of fraud that the beneficiary undertakes this fraud or that this fraud is done with his knowledge or his tacit approval, but there must also be a causal relationship between the fraud activities that inspired the administration and the issuance of the decision, so that if it were not for these actions, the decision would not have been issued, or It should have at least a significant weight in issuing the decision (Eisenmann, 1982). If an individual applies to fill a specific position and presents an unrealistic certificate that he previously held a similar position, and this condition was not required by law, then the appointment decision cannot be considered defective for this reason. However, the situation changes if the administration had taken into consideration this certificate and granted the candidate priority over his colleagues based on it (Renard, 2014), so these acts of fraud must be so clear that they should not be assumed, but must be proven according to what was applied French administrative court (Broché, 2009).

In one of its recent verdicts,the French State Council has defined the legal nature of the illegality of this decision, as he considered that the decision based on fraud is a decision that came as a result of a material error of the administration lies in its uncertainty and verification of the material facts on which its decision was based, that the fraud is the main reason for administrative authority to issuing its decision. In addition, to be noted that the fraud is usually committed before the decision is issued or in the stages of its issuance, or when the decision was issued without it, then it will be legally the reason for issuing the decision, and therefore this decision is considered defective. As for the case of cheat or fraud itself, it is only an exceptional case that makes the decision without legal effect in the event that fraud is discovered, and thus allows the administration to withdraw it at any time without adhering to the deadline for appeal (F.S.C., 5 Feb. 2018, Cora Company, op.cit)

\section{The Impacts of the Decision based on Fraud and the Means to Prove it}

\subsection{The Impacts of the Decision based on Fraud}

The decision issued by the administration upon cheat or fraud by individuals has some important legal effects as follows:

\section{First: Absence of the Will of Administrative Authority}

It is recognized that any legal action must have the element of will, otherwise this work has descended to the level of material actions that may happen accidentally without the availability of an effective will.Consequently, the administrative decision as a legal action must have the element of the will of the decision-maker (Chapus, 2002; Frier\& Petit, 2012).

The jurisprudence of common law in France unanimously states that an administrative decision is born as soon as there is a will element or the intention. The existence or absence of the decision revolves around the availability of the administration's intention to issue the decision, regardless of its validity and legitimacy, which made defects of 
consent a major impact on the null decision if the will of the person who issuing the decision wasdefected of such defect (Hauriou, 2009; Pacteau, 2001; Rivero\&Waline, 1996; Panchaud, 1962)

The French State Council affirmed that the element of will revolves around existence and non-existence with the administrative decision, as there is no will and no decision, as it embodies the individual will of the administration (F.S.C., 28 fév. 1996, Fauqueux, Rec., P. 397).

Given that the theory of null decision is considered one of the most accurate theories of administrative law, the French Government Commissioner (Galabert) clarified some basic differences between the decision based on fraud and the null decision.He said that: "If the result is the same with respect to the decision based on fraud that plunges the administrative decision to the point of absence and between the decision that is not due to other reasons represented in the demolition of the time-barrier and giving the administration complete freedom to revoke this decision at any time, there are basic differences between the two cases that can be summarized as follows: (Galabert1967)

1- The idea of fraud lies in the old concept of administrative ethics, and the necessity of this principle in dealing with administrative authority, while the idea of null lies in preventing the abuse committed by the administrative authority.

2- In the case of fraud, there is a personal practice by individuals that led the administration to act deviant, the role of the individual is clear in deluding the administration to issue the decision, but in the case of absence, we are facing an administrative practice that violates the principles, the administration in the case of the null decision does not act inspired by the beneficiary, in contrast to the decision based to cheat.The null decision does not have any effect, while a decision based on fraud can have effects, even if they are temporary, as long as the fraud actions are not exposed. The French State Council referred to this fact, as it considered that the decision taken based on fraud or cheat remains productive to its effect as long as the administration or judge has not discovered the case of fraud and cheat". (F.S.C., 23 Apr 2003, Society. Bouygues Immobilier, Req. N²49712)

3- The judge's role in the case of null decision is much easier than in the case of a decision based on fraud, since the null decision is evident to the judge so that it does not require effort and hardship from him, while his role here is limited to determining the null decision and the lack of its legal effect, In the case of a decision based on fraud, the judge must make an effort to reveal fraud and deceptive methods, and verify the extent of their impact on the issuance of the decision".

\section{Second: It is Permissible to Withdraw a Decision based on Fraud at any Time}

French administrative jurisprudence has established that if the administration makes a decision that was taken based on the practice of cheat or fraudulent methods by the stakeholder or the beneficiary of the decision, then such a decision is based on a case of fraud against the administration, therefore this decision is not entrenched by the deadline of the withdrawal deadline (sixty days). Whenever this fraud is found, the administration can withdraw this decision at any time without any time restrictions (Boulouis, 2008). This is an application of the established rule of common law jurisprudence that "fraud spoils everything" (Auby\&Drago, 1992; Debbasch\& Ricci, 2001).

The same ruling applies to the administrative decision issued as a result of the behavior of the person concerned that does not rise to the level of fraud, but it has caused the administration to mistake it for the issuance of this decision. Such a decision, like the decision issued as a result of fraud, can be challenged by cancellation and withdrawal at any time, without being restricted by that sixty days (Delvolvé, 2003, Marceau \&Delvolvé, 2009).

On the other hand, one of the most prominent French jurists pointed out that if the law had sacrificed one of its origins - it is respect for legitimacy - it permitted defective decisions to be entrenched by the deadline of the withdrawal deadline in order to stabilize the status and legal centers and to protect the rights acquired by individuals, the legal reasoning and the rules of justice require the waste of these principles in the case of individuals resorting to the use of fraud or fraudulent methods that directly affected the administration's will to issue some decisions, such decisions are not worthy of legal protection, which requires allowing the administration to withdraw it without being bound by a specific date, as the principle in dealing with administrative authority is goodwill, therefore, no one should benefit from dealing with the administration based on an act involving cheat or fraud by his side (Delvolvé, 2003), as stated by the government's commissioner (Galabert) when he said that the cheater should not be allowed to compel the administration to guarantee the claimed rights upon a fortification decision over time (Galabert, 1967).

The French legislator established this principle in the Law on Relations between Individuals and Administration in Article $(241 / 2)$ which states that: "It is permissible to cancel or withdraw any individual administrative decision obtained by fraud at any time". The favor of the determination of this principle due to the diligence of the French State Council in this regard, as the determination of this principle is originally due to his ruling in the case (Sarovitch) whose facts are summed up by Mr. Sarovitch obtaining French citizenship in fraudulent ways, after the 
matter was discovered by the authority of the nationality donor, the latter withdrew the decree granting him the nationality, then he appealed the decision before the

French State Council due to completion of time to withdraw the decision (sixty days). The deception of concealing the truth of his past, which does not entail an acquired right to obtain French citizenship (F.S.C., 15 Apr 1955, Sarovitch, Rec., Lebon, 1956, p. 520).

After that, the French State Council's decisions in this regard successively, confirming the administration's right to withdraw its decisions based on fraud, without being bound by any time restrictions.

In a recent verdict of the French State Council, it was decided that the municipality has the right to withdraw the building permit at any time after it was determined that it had been obtained fraudulently, this matter could not establish a right for its affiliates, which makes the decision to grant the license null decision (F.S.C., March 18, 2015, Ass., Defense League of the Alpilles, req N³67491).

\subsection{Evolution of Means to Prove Cheat and Fraud in the French State Council's Jurisdiction}

By extrapolating the French administrative judgments related to the means of proving cheat and fraud in the administrative decisions, the most prominent of these methods can be concluded as following:

\section{First: Providing Administrative Authorities with Misleading or False Information}

The French administrative judge managed to find a case of cheat and fraud against the administration by checking the information provided to the administration by individuals to obtain a building permit (Pontier, 2012). The Administrative Appeals Court (A.A.C.) in Marseille decided on February 7, 2008 that, given all the information and data mentioned, it will be mistake if we said that the judges of the Marseille Administrative Court considered that Ms. (Phalipou) had obtained the building permit issued on December 27, 2001 after it was proven that she had deliberately provided false information to the municipality to obtain that license. As for fraudulent acts, the rule is clear in this regard, as the decision obtained by fraud with the intent to mislead the administration intentionally is not a reason for creation rights, so it is considered a reason for the possibility of withdrawing the decision at any time as in the case of the null decision. As a result, there is no justification for objecting to the revocation of this license retroactively to remove all its implications, here it is not stated that the mayor of the municipality was unable to withdraw building permits for the expiry of the revocation period (A.A.C.,of Marseille, 7 feb. 2008, $\mathrm{N}^{\circ}$ 07MA0141).

This is the method which was used by the French State Council in one of its recent provisions to prove the fact of cheat and fraud against the administration authorities, as it stipulated that one of the persons submitted an unrealistic building plan in line with the conditions for a specific piece of land in order to obtain a building permit, and that it was proven to the administration after issuing this license, the applicant must practice a form of fraud on the administration, by giving it unreal information about the building plan intended to be erected, with the aim of misleading and deceiving the administration, such a decision is based on the use of cheat and fraudulent methods to influence the administration's will to obtain the building permit (F.S.C., 9 oct. 2017, Société Les Citadines, N ${ }^{\circ}$ 398853)

In another case, the French State Council was able to detect the presence of cheat and fraud after verifying that the information provided to administrative authority by someone is false information intended to mislead the administration to obtain a decision to grant him residence in France. This case is summarized in the fact that a foreigner obtained a residence card in France through fraud and deception, as he accused the concerned French authorities that he was mentally ill because of the turmoil in his country, so he decided to migrate to France to avoid these disturbances and temptations prevailing in his country, except that after obtaining the residence card it is revealed to the administration after conducting the medical examination that the applicant does not really suffer from any mental illness that affected his health and that he is in good health, but he fabricated this disease as a way to trick the administration in order to influence its will to grant him a residence card, so the administration withdrew the decision to grant residency and to consider it as if it wasn't not. Upon the arrival of the case to the French State Council, the Council recognized the administration's right to withdraw the decision of granting residency at any time without being bound by the withdrawal dates based on the fact that the decision was issued based on an artificial reason from the person concerned involving a case of cheat and fraud against the administration (F.S.C., August 3, 2017, SRIFI, Rec., Lebon, N 238918)

\section{Second: The Contradictory Information Provided to Administrative Authority}

In one of its recent decisions, the French State Council has been able to prove the existence of cheat and fraud - not only on the basis that the building permit file contains incorrect information regarding the nature of the land - but also by comparing the documents in the building permit file with those related to a previous application for a permit based on the same land, where the council was able to detect the existence of fraud from the applicant by contradicting the information that the applicant himself provided in the current and previous application; 
The previous request contains an indication that the land is not suitable for the establishing the project due to its steep decline, while this information was hidden and the facts changed in the subsequent application for licensing in order to obtain a decision to grant the license, this was proven through the topographical survey of the plot of land intended to establish the project on it (F.S.C., August 16, 2018, Société NSHHD, N ${ }^{\circ} 412663$ ).

The French State Council has indicated in the same decision that it cannot be considered that concealing this information related to the inclination of the land is false and simple information, it actually refers to a deliberate fraud from the applicant because ignoring this information in the new application has benefit for the petitioner to compel the administration to accept his request to grant the license (French State Council's comment on the previous decision on the website: https://www.legifrance.gouv.fr).

It should be noted in this context that there is an aspect of French jurisprudence that has indicated the possibility of revealing the existence of fraud practiced by individuals against the administration authorities by way of conflicting information provided by individuals before the council expressly declares it in the aforementioned verdict. For example, an employee provided information about his pension rights that contradicted those specified in the employment contract (Waquet, 2000; Huteau, 2015).

\section{Third: Concealing Basic Information against Administrative Authority}

The French administrative judiciary has settled on the fact that intentionally keeping silent about providing the administration with some basic information and hiding it constitutes a form of cheat and fraud against the administration if it is established that the administration would not have issued the decision if it had known this incident or this circumstance (Latournerie, 2005; Ribes, 2014).

On the basis of this, the French State Council ruled that Mrs. Papegnies deliberately concealed medical reports that disclosed her health condition and her concern not to be informed the administration about it, that the decision issued for her appointment had resulted in a case of cheat and fraud, considering that the administrative decision does not create rights, and therefore it can be withdrawn or canceled despite of the expiry of the legal withdrawal period (F.S.C., Section, 29 November. 2002, Assistance publique-Hôpitaux de Marseille, op.cit)

\section{Conclusion}

The idea of cheat and fraud in administrative law is considered as an independent theory that is not subject to the provisions of criminal or civil law, as confirmed by the French administrative judiciary. It is also independent from the theory of null decision, but it is similar to it in terms of legal effect. This idea is of an intentional nature, provided when a person usesa fraudulent method with the intention of misleading the administration to reach an illegal purpose. It is also of a personal nature that goes out to punish the fraudulent person himself and depriving him of the benefit of the fraud-based decision, but not go away to anyone who benefited from this decision if he has no knowledge about fraud. Likewise, the silence of the beneficiary from the decision, to alert the administration about the material mistake that it committed, when knowing it, amounts to fraud.

The decision which issued on the bases of cheat and fraud is an exception to the principle of the stability of the personal legal statuses of individuals, as these statuses do not settle, no matter how long ago, because it is a decision that is born dead which will not create rights for its owners. Therefore, the administration can withdraw it at any time.

Because proving the fact of cheating against the administrative authorities requires proving personal or psychological elements, including the intention to circumvent the administration intentionally, the French State Council tends to expand the scope of proving cheat and fraud in the administrative decision and developing means to prove it in all possible ways, as it recently invented a new means for this purpose, such as conducting a comparison between the requests that submitted by the concerned person that relates to the same decision to detect the presence of cheat or fraud.

Finally, this study recommends that the administrative and judicial authorities, within the framework of enhancing jointed cooperation, to pay attention to the phenomenon of widespread cheat or fraud in public and private facilities in the state.

\section{References:}

Auby (J-M.) and Drago .R.(1992). Treatise on administrative appeals, Litec, Paris.

Austry (S.). (2004). Withdrawal and repeal: the case of acts with a pecuniary object and acts obtained by fraud, RFDA, Paris.

Auvret (P.).(1985).The concept of acquired rights in French administrative law, RD publ.

Broché (F.).(2009).The great judgments of administrative jurisprudence, 17th ed., Dalloz, Paris.

Boulouis (N.).(2008).Limits of the creation of rights under conditions, RFDA, Paris.

136 
Chapus (R.).(2002).Droit du contentieux administrative, 10 éd.,Montchrestien, Paris.

Chapus, (R.).(2001).Droit administrative générale, T.1, Montchrestien, Paris.

Daniel (B.). (2017). Report: Fight against fraud in social benefits: at what price for the rights of users, September.https://www.defenseurdesdroits.fr/sites/default/files/atoms/files/rapportfraudessociales-v606.09.17_0.pdf

De Laubadère (A.) and Gaudemet (Y.).(2001).Triaté de droit administrative, T.1, 16éd., L.G.D.J., Paris.

Debbasch (Ch.) and Ricci (J-C).(2001).Administrative litigation, 8th ed., Dalloz, Paris.

Delvolvé (P.).(2003).Withdrawal and obligation: the case of acts with a pecuniary object and acts obtained by fraud, RFDA, Paris.

Eisenmann (Ch.).(1982).Course in administrative law, t. 1, LGDJ, Paris.

Frier (P-L) and Petit (J.), (2012), Administrative law, Montchrestien, coll. DomatDroit public, 7th ed., Paris.

Forge (J-M).(2002).Administrative law, P.U.F., Paris.

Galabert (L.). (2018). Commentary on the F.S.C., August 16, 2018, SociétéNSHHD,N ${ }^{\circ} 412663$. https://www.legifrance.gouv.fr/affichJuriAdmin.do?idTexte=CETATEXT000007634984

Giraud (M.). (2014). The mayor can withdraw a permit obtained by fraud at anytime, Letter $\mathrm{N}^{\circ} 251$ of February13, 2014.http://www.urbanismepratique.com/article-le-maire-peut-retirer-anytime-a-license-obtained-byfraud-17291.html

Hauriou (M).(2009).Administrative authority: Theoretical study of administrative law, Bibliobazaar, Paris.

Huteau (G.).(2015). The control of the judge on the administrative sanctions of the organizations of Social security, Litigation social protection, $\mathrm{N}^{\circ} 47$, March 2015.

Latournerie (D.).(2005). The Council of State, Dalloz knowledge of the law, Paris.

Marceau (L.). Delvolvé (P.) and others.(2009).The great judgments of administrative jurisprudence, 17th edition, Dalloz, Paris.

Odent (R.).(1981).Administrative litigation, Les Cours de droit, Fasc., Paris.

Panchaud (A.).(1962).The administrative decision, Comparative study, International review of comparative law, Vol. 14 No. 4, October-December 1962.

Pontier (J-M.).(2012).Milestones for a legal approach to nuclear safety, in "Nuclear law - Nuclear safety", dir. J-M. Pontier and E. Roux, University of Nîmes Center for Administrative Research.

Renard (S.).(2014).The administrative act obtained by fraud an act creating precarious rights, A.J.D.A.,Dalloz, Paris.

Ribes (D.).(2014).The new principle "Silence of the administration is worth acceptance": A.J.D.A, Dalloz, Paris.

Rivero (J.) and Waline (J).(1996).Administrative law, Dalloz, Paris.

Pacteau (B.), (2001), Administrative law, P.U.F., Paris.

Santulli (C.).(2001).Acquired rights, RFDA, Paris.

Sauvé (J-M.).(2011).Fraud and social protection, Speech, February 11, 2011, Paris.

Waquet (Ph.).(2000).Free remarks on outsourcing, SemaineSocialeLamy, Paris.

Yannakopoulos (C.).(1997).The concept of acquired rights in French administrative law, LGDJ, Paris. 